\title{
PEMBIASAAN CINTA AL-QUR'AN DAN HADIST PADA ANAK USIA DINI UNTUK MEMBENTUK KARAKTER ISLAMI SISWA PADA PAUD NUR AL-BANNA GERUNG
}

\author{
Rosada $^{1}$, Sipa Sasmanda ${ }^{2}$ \\ ${ }^{1,2}$ Dosen Program Studi Pendidikan Sejarah FKIP, Universitas Muhammadiyah Mataram \\ Email : ros_ada@yahoo.com
}

\begin{abstract}
ABSTRAK
Penelitian ini tentang pembiasaan Al-Qur'an dan Hadist untuk membentuk karakter islami anak. Tujuan penelitian ini adalah bagaiamana membentuk karakter islam pada anak usia dini. Metode yang digunakan adalah Jenis penelitian kualitatif yaitu memaparkan semua fenomena yang terjadi selama dalam setting penelitian. Alasan menggunakan pendekatan ini bertujuan untuk menggambarkan keadaan suatu fenomena yang terjadi, dan berusaha memamparkan data sebagaimana adanya tentang bagaimana program cinta AlQur'an untuk menumbuhkan karakter islami pada siswa PAUD NurAl-Banna. Hasil Bagi siswa dapat memberikan motivasi serta dapat menumbuhkan cinta Al-quran yang akan mencerminkan kehidupan islamiProgram yang dilaksanakan sekolah PAUD Nur Al-Banna untuk menumbuhkan karakter siswa denagna cara mengutamakan bagi siswa untuk mengaplikasikannya kedalam kehidupan sehari-hari setelah dihafal atau sudah dipelajari. Adapun contoh yang dilakukan adalah menghafal hadist dan dalil yang ada dalam Al-Qur'an seperti hadist larangan marah, hadist anjuran bersih dan indah, dan lain sebagainya. Program tersebut mampu mengolah pikir, hati, raga, sehingga dari aspek kognitif, aspek psikomotorik, dan aspek afektif sehinga semua aspek tersebut berjalan selaras. Adapun hambatannya adalah Proses sudah bisa terlaksana akan tetapi masih belum maksimal, dikarenakan proses tersebut memiliki hambatan-hambatan yang dialami siswa. Hambatan mesti akan terjadi jikala salah satu pihak tidak mendukung pelakasanaan tersebut. Contohnya di sekolah siswa diharuskan menggunakan pakaian yang sopan akan tetapi di rumah mereka bebas sehingga aturan tersebut hanya berlaku di sekolah saja di rumah tidak, hal tersebut karena peran orang tua dalam program tersebut kurang sehingga untuk masalah tersebut masih belum maksimal. Adapun pembiasaan tersebut seperti memakai jilbab atau berpakain yang sopan, makan dengan tangan kiri, berkata tidak baik, dan lain sebagainya.
\end{abstract}

Kata Kunci: Pembiasaan Al-Qur'an dan Hadist, Karakter Islam

\section{PENDAHULUAN}

Al-Quran merupakan pedoman hidup manusia sehingga akan memeperoleh kehidupan yang sesuai dengan ajaran islam. Di dalam Al-Qur'an Allah mengajarkan agar manusia bisa mengambil pedoman hidupnya dalam kehidupan sehari-hari, karena Al-Qur'an mengajarkan syariat islam mulai dari hal yang kecil hingga permasalahan yang besar. Salah satu tatanan yang harus dilaksanakan adalah bagaimana menata prilaku kita sebagai manusia yang memiliki hubungan sosial dengan masyarakat, melihat kondisi bangsa kita yang memiliki kemerosotan moral, sehingga penting untuk memperbaiki dan menanamkan pendidikan karakter yang baik pada siswa. Tujuannya adalah untuk mewujudkan manusia yang berakhlaq mulia dan bermoral baik, sehingga kelangsungan hidup dan perkembangan manusia dapat dijaga dan dipelihara.

Terkait dengan hal tersebut lihat saja tujuan pendidikan menurut undang-undang tahun 2003 dalam undang-undang guru dan dosen adalah" Membentuk watak serta peradaban bangsa bermartabat dalam rangka mencerdaskan kehidupan bangsa, pendidikan nasional bertujuan untuk mengembangkan potensi siswa menjadi insan beriman dan bertakwa kepada Tuhan Yang Maha Esa, berakhlak mulia, sehat, berilmu, cakap, kreatif, mandiri, dan menjadi warga negara demokratis serta bertanggung jawab, memiliki karakter. Tujuan tersebut yang harus digaris bawahi adalah menjadi manusia yang memiliki tanggung jawab, berakhlaq mulia dan 
berkarakter. Oleh karena itu, untuk membentuk pribadi yang berkarakter, diperlukan semua pihak keluarga, sekolah, pemerintah, dan seluruh komponen yang ada dalam masyarakat.

Perilaku seseorang ditentukan oleh lingkungan, artinya seseorang akan menjadi pribadi yang berkarakter apabila tumbuh pada lingkungan yang berkarakter. Melalui pembiasaan mencintai Al-quran sejak dini akan mampu terbiasa dengan membaca, dan menghafal. Fase berikutnya memahami dan mengamalkannya ke dalam kehidupan seharihari. Kebiasaan ini tumbuh dalam pribadi siswa seperti disiplin, bersih, bertanggung jawab, jujur, berjiwa social, kreatif, braakhlaq mulia dan lain sebagainya. Nilai-nilai tersebut tumbuh dalam personality siswa karena lingkungan mereka sangat mendukung, contohnya dalam kehidupan sehari-hari siswa harus intens untuk membaca Al-quran, dalam aktivitas tersebut dimulai dengan berwudhu akan mencerminkan kebersihan dalam kehidupan siswa. Istiqomah atau terus menerus akan mencerminkan kedisiplinan yang tinggi untuk siswa, dengan demikian dari nilai-nilai tersebut tumbuhlah pendidikan karakter islami untuk siswa.

Karakter merupakan (daya qolbu) yang merupakan saripati kualitas batiniah atau rohaniah manusia yang penampakannya berupa budi pekerti sikap dan perbuatan lahiriah, sedangkan pendidikan karakter bisa dibentuk dan dibina melalui pembiasaan setiap hari. Pembiasaan dilakukan dengan menerapkan kepada siswa gemar membaca dan menghafal Al-qur'an. Melalui program pembiasaan membaca Al-quran siswa akan dibina untuk memiliki akhlaq dan prilaku yang baik sehingga akan tercipta masyarakat baldatun toyyibatun warabbun gafur. Terbentuknya masyarakat baik itu harus dilandaskan dengan pendidikan umum dan islam sehingga akan seimbang dalam kehidupan antara kehidupan dunia dan akhirat, itu merupakan tujuan orang tua, guru, masyarakat bahkan pemerintah tetapi tidak sesuai dengan kenyataan yang kita temukan di lapangan. Contohnya siswa-siswa seperti siswa PAUD lebih senang dengan lagu-lagu dangdut yang bikin heboh, itulah yang mereka tiru, untuk itulah guru menguapayakan agar mereka bisa mengubahnya dengan mencintai Al-Quran.

\section{KAJIAN TEORI}

Al-Qur'an adalah firman Allah yang diturunkan kepada nabi Muhammad SAW melalui malaikat jibril yang merupakan mukjizat terbesar sepanjang sejarah manusia, dan siapa yang membacanya maka aakan mendapatkan ganjaran pahala yang sangat besar. Pendapat lain Al-quran merupakan perkataan yang diturunkan dari Allah yang maha tinggi lagi maha besar kepada nabi Imuhammad SAW, beserta teks dan maknanya. Membacanya dinilai sebagai ibadah dan dia merupakan mukjizat yang membuat makhluk tidak mampu membuat yang semisal dengannya.

Al-Quran merupakan pedoman hidup manusia sehingga akan memeperoleh kehidupan yang sesuai dengan ajaran islam. Di dalam Al-Qur'an Allah mengajarkan agar manusia bisa mengambil pedoman hidupnya dalam kehidupan sehari-hari, karena AI-Qur'an mengajarkan syariat islam mulai dari hal yang kecil hingga permasalahan yang besar. Salah satu tatanan yang harus dilaksanakan adalah bagaimana menata prilaku kita sebagai manusia yang memiliki hubungan sosial dengan masyarakat

Al-qur'an yang dijadikan sebagai pegangan hidup seyogya nya lah kita sebagai umat nabi Muhammad mampu mengaplikasikannya ke dalam kehidupan sehari-hari, sebagaimana yang telah di contohan rasululloh. Oleh karena itu, Al-qur'an dijadikan sebagai pedoman akan kita cintai sehingga mampu melaksanakan ajaran yang diperintahkan Allah.

Menurut (Musfiroh, 2008: 27) karakter mengacu pada serangkaian sikap prilaku (behavior), motivasi (motivations), dan keterampilan (skills), meliputi keinginan untuk melakukan hal yang terbaik. Karakter menurut Slamet yang diungkapkannya pada seminar Nasioanal 28 Juni 2009, bahwa karakter itu meruapakan jati diri (daya qolbu) yang merupakan saripati kualitas batiniah atau rohaniah manusia yang penampakannya berupa budi pekerti (sikap dan perbuatan lahiriah).

Dengan demikian siswa membutuhkan pendidikan berkarakter yang 
akan membentuk karakter positif. Pendidikan karakter penting karena hasil pendidikan tidak sesuai dengan tujuan pendidikan, apalagi melihat fenomena di kalangan remaja. Dekadansi moral semakin meningkat disebabkan pendidikan tidak menyentuh aspek apektif, sehingga prilaku siswa tidak mencerminkan manusia yang memiliki karakter baik, yang ada hanyalah siswa yang cerdas tetapi memiliki emosi tumpul, untuk itulah guru perlu mendidik siswa agar memiliki karakter positif. Untuk itulah guru mengupayakan pendidikan karakter agar siswa memiliki karakter positif.

Menurut Megawangi dalam (Darmiyati, 2004: 110) mendefinisikan pendidikan karakter sebagai sebuah usaha untuk mendidik anak-anak agar dapat megambil keputusan dengan bijak dan mempratikkannya dalam kehidupan seharihari, sehingga mereka dapat memberikan kontribusi yang positif pada lingkungannya.

Menurut (Darmiyati, 2006: 5) sistim pendidikan yang sesuai untuk menghasilkan kualitas masyarakat yang berkarakter positif adalah yang bersifat humanis, yang memposisikan subjek didik sebagai pribadi dan anggota masyarakat yang perlu dibantu dan didorong agar memiliki kebiasaan efektif, perpaduan antara pengetahuan, keterampilan, dan keinginan. Perpaduan ketiganya secara harmonis menyebabkan seseorang atau suatu komunitas meninggalkan ketergantungan menuju kemandirian dan saling ketergantungan. Kesalingtergantungan sangat diperlukan dalam kehidupan modern, karena kehidupan yang semakin kompleks hanya dapat diatasi secara kolaboratif, untuk itu diperlukan keterampilan membangun hubungan yang serasi.

\section{METODE PENELITIAN}

A. Jenis Penelitian

Jenis penelitian ini merupakan penelitian kualitatif yaitu memaparkan semua fenomena yang terjadi selama dalam setting penelitian. Alasan menggunakan pendekatan ini bertujuan untuk menggambarkan keadaan suatu fenomena yang terjadi, dan berusaha memamparkan data sebagaimana adanya tentang bagaimana program cinta Al-Qur'an untuk menumbuhkan karakter islami pada siswa PAUD NurAl-Banna

\section{B. Tempat dan Waktu penelitian}

Pendidikan anak usia dini (PAUD) Nur Al-banna Biletepung, Desa Beleke, kecamatan gerung dipilih sebagai tempat penelitian karena sekolah ini terletak di wilayah yang sangat strategis, ditengah sawah berdampingan dengan perkampungan sehingga mudah untuk dijangkau oleh siswa dan orang tua bisa langsung memantau kegiatan siswa. Adapun waktu penelitian dilakukan pada bulan September sampai bulan November 2014

\section{Subjek dan Objek Penelitian}

Penelitian ini dilakukan secara menyeluruh tentang bagaimana program cinta Al-Qur'an untuk menumbuhkan karakter islami pada siswa PAUD Nur-Albanna. Tujuanya adalah untuk menggali data yang dibutuhkan dalam rumusan masalah yang telah dipaparkan. Subjek penelitian diambil dengan cara memilah data sesuai dengan yang diinginkan, untuk itulah pada penelitian ini ditekankan pada bagaimana program cinta AlQur'an untuk menumbuhkan karakter islami pada siswa PAUD nur-Albanna. Adapun subjek penelitian berkaitan langsung dengan bagaimana program cinta Al-Qur'an untuk menumbuhkan karakter islami pada siswa PAUD nur-Albanna. Sedangkan objek penelitiannya adalah guru, siswa, orang tua dan masyarakat

Deknik dan Instrumen
Pengumpulan Data
Peneliti bertindak sebagai key
instrument, karena peneliti sebagai pengumpul data yang utama. Key instrument kapasitasnya bertindak sebagai perencana, pelaksana pengumpulan data di lapangan, sekaligus sebagai analisis dan pelapor hasil penelitian. Sumber data berupa perkataan atau perbuatan dari informan yang mengarah pada fokus penelitian. Agar memperlancar penelitian digunakan instrumen pendukung. Untuk pengumpulan data melalui teknik wawancara digunakan pedoman wawancara, untuk teknik observasi digunakan pedoman observasi, sedangkan untuk dokumentasi digunakan analisis dokumentasi. Adapun instrumen lain yang digunakan untuk mendukung pengumpulan data adalah catatan lapangan dan catatan observasi. 
Proses pengumpulan data dilakukan dengan menggunakan buku catatan, atau alat perekam. Untuk memperoleh data yang akurat terlebih dahulu digunakan strategi. Strategi yang digunakan dalam setting penelitian ini adalah sebagai guru mendekati terus siswa yang cuek, tidak pernah peduli dengan atuan dan tata tertib dan lain sebagainya.

Untuk mendalami masalah penelitian, sehingga memperoleh hasil yang maksimal, diperlukan waktu yang relatif lama. Waktu penelitian adalah bulan September sampai bulan November tahun 2014, tiga bulan tersebut dianggap cukup untuk menyerap informasi yang dikaji, maka untuk sementara dianggap selesai. Bila dikemudian hari masih ada data yang diperlukan, dapat berkunjung kembali ke sekolah tersebut untuk melengkapinya. Setelah dianggap tuntas, kemudian konsultasi kepada kepala sekolah, guru dan lainnya.

Untuk memperlancar penelitian, digunakan teknik dalam mengumpulkan data antara lain:

1. Observasi

Penelitian ini menggunakan pengamatan secara langsung tentang kondisi yang terjadi di lapangan, baik kondisi fisik maupun prilaku yang terjadi di lapangan selama penelitian berlangsung. Observasi menempati posisi sentral dengan mengoptimalkan peran kemampuan peneliti untuk melihat objek penelitian dalam menangkap arti fenomena di lapangan, observasi ini dilakukan secara langsung dan partisipasif.

Observasi yang dilakukan adalah proses bagaimana program cinta Al-Qur'an untuk menumbuhkan karakter islami pada siswa PAUD Nur-Albanna. Kegiatan belajar mengajar dari awal sampai akhir direkam untuk mengetahui kreativitas guru yang diciptakan, seperti di awal pembelajaran guru memberikan motivasi, menggunakan metode yang relevan, dan memberikan evaluasi. Evaluasi tersebut beertujuan untuk mengetahui hasil pembelajaran.

\section{Wawancara}

Teknik wawancara bertujuan mengetahui fenomena secara mendalam sehingga akan mencapai data yang lebih akurat. Adapun wawancara ini ditujukan kepada informan terpilih dengan pertimbangan relevansi dengan tujuan penelitian. Teknik ini digunakan untuk melengkapi data yang diperoleh ketika melakukan observasi sebagai bentuk triangulasi data.

3. Dokumentasi

Penelitian ini menggunakan teknik pengumpulan data dengan cara memanfaatkan dokumen bahan tertulis, sehingga peneliti bisa menggunakan dokumen dengan cara menyelidiki buku-buku, catatan harian, dokumen, peraturan, dll. Peneliti memanfaatkan teknik dokumentasi untuk mengetahui sejarah, latar belakang, perkembangan dan proses yang sedang dilakukan guru dalam bagaimana program cinta Al-Qur'an untuk menumbuhkan karakter islami pada siswa PAUD Nur Al-Banna.

\section{E. Keabsahan Data}

Terdapat beberapa teknik uji keabsahan data yang dapat dilakukan dalam penelitian yang disesuaikan dengan kriteria dan teknik pemeriksaan yaitu dengan cara memperpanjang waktu penelitian dan menguji dengan teknik triangulasi. Teknik triangulasi dimaksudkan untuk memperoleh derajat kepercayaan yang tinggi. Triangulasi merupakan proses menemukan kesimpulan dengan mengecek ulang dari berbagai sudut pandang.

\section{F. Teknik Analisis Data}

Langkah selanjutnya, setelah data lapangan terkumpul, peneliti menganalisis data. Untuk menghindari kekeliruan dan penumpukan data, sehingga dapat mengakibatkan tereduksinya validitas dan kreadibilitas data. Analisis yang dilakukan dengan menggunakan analisis interaktif, terdiri dari tiga alur yang berjalan secara simultan yaitu reduksi data, penyajian data, dan penarikan kesimpulan. Menurut (Matthew, 1992: 16) reduksi data adalah proses pemilihan, pemusatan perhatian pada penyederhanaan, pengabstrakan, dan transformasi data kasar yang muncul dari catatan-catatan tertulis di lapangan.

\section{HASIL PENELITIAN DAN PEMBAHASAN}

Pendidikan karakter harus dilaksanakan sejak usia dini, karena usia tersebut merupakan periode perkembangan yang sangat penting dalam kehidupan 
manusia. Pada masa ini seluruh istrumen besar manusia terbentuk, bukan kecerdasan saja tetapi seluruh kecakapan psikis. Para ahli menamakan priode ini sebagai gold ags atau masa keemasan perkembangan. Pendidikan anak usia dini sangat penting karena akan menentukan kualitas SDM di masa depan.

Hal ini disebabkan karena masa pembentukan otak manusia terjadi paling cepat pada anak usia dini, apalagi pemebentukan karakter islami dengan membiasakan AlQur'an dan Hadist. Al-Qur'an dan Hadist kalau tidak dari sejak dini dibiasakan maka sulit untuk diterapkan, misalkan saja untuk menghafal dan mengaplikasikannya.

Pembentuk karakter siswa dengan membiasakan siswa untuk menghafal Al-Quran dan hadist. Program ini selain membutuhkan hafalan membutuhkan aplikasi juga kepada siswa dalam kehidupan sehari-hari. Tujuannya untuk melatih aspek kognitif dan afektif, karena kalau sudah menghafal maka harus diaplikasikan. Contoh program tersebut yang sesuai dengan larangan, misalkan hadist tentang larangan marah seperti "la tagdof wa lakakal jannah" artinya janganlah marah bagimu surga. Sehingga hadist tersebut dijadikan sebagai senjata bagi siswa ketika berhadapan dengan teman, guru. Orang tua di saat marah, sehingga terkadang dari hadist tersebut para orang tua nyadar diri.

Selain itu ada hadist anjuran untuk melaksanakan kebersihan, "annazofatuminal iman" kebersihan itu sebgaian dari iman atau "Attohuru yuhibbu" allah menyukai yang indah. Hadist tersebut dimanfaatkan agar siswa menyukai kebersihan, aplikasinya ke dalam kehidupan sehari-hari adalah siswa dituntut untuk hidup bersih seperti sebelum makan cuci tangan, tidak membuang sampah sembarangan, gosok gigi sebelum tidur dan sesudah makan, kebiasaan itu memang sepele perbedaan yang mereka lakukan adalah siswa selalu memulai pekerjaan tersebut dengan menyebut asma Allah, sehingga semua yang mereka lakukan tidak sia-sia dan berdasarkan Ridho Allah.

Sedangkan dari Al-Qur'an misalnya untuk memotivasi siswa dalam hal menuntut ilmu "tolabul ilmu faridatun alla kulli muslimin" Menuntut ilmu itu wajib bagi setiap muslim dan muslimat. Sehingga motivasi itu yang membuat mereka untuk belajar, dari motivasi tersebut menghasilkan energi yang menginginkan siswa untuk terus belajar.

Itu salah satu programnya, selain itu jika ada lagu-lagu yang biasa dinyayikan siswa-siswa sekolah lain yang tidak mendidik maka lirik lagu tersebut kita ganti menjadi yang mendidik, sehingga kesan dari lagu tersebut sesuai dengan maknanya, seperti lagu "balonku ada lima" lirik lagu terakhirnya adalah hatiku sangat kacau akan tetapi kita ganti dengan hatiku tetap ceria, itu menafsirkan bahwa hanya gara-gara balon yang meletus menjadikan kacau, seolah-olah itu menggambarkan siswa yang cengeng.

Akan tetapi jika diganti tetap ceria anak itu akan terdidik menjadi seorang personality yang tangguh, bahwa tidak perlau kacau kalau balonnya meletus, karena masih ada balon yang lain. Masih banyak lagu-lagu mendidik yang diajarkan siswa, sehingga walaupun banyak lagu tetapi kita menyeleksi lagu-lagu yang islami, mendidik sehingga siswa di mine set menjadi siswa yang unggul dalam prestasi, kuat jiwa dan raganya serta pemikirannya islami.

\section{A. Pembahasan}

Karakter yang dimiliki seseorang tidak bisa diwariskan, dijual beli, atau ditukar dengan uang, karena karakter itu adalah personality dari setiap orang. Karakter itu cerminan prilaku sesorang yang akan menjadi ciri khas seseorang. Karakter ibarat iman yang tidak bisa diwariskan kepada siapa saja seperti yang lain, karena sudah melekat pada diri manusia itu sendiri, sehingga jika ada orang tua menginginkan anaknya memiliki karakter baik tanpa usaha maksimal itu hanya imposible.

Karakter itu merupakan jaminan dari prilaku seseorang baik buruknya sehingga untuk memperolah itu membutuhkan usaha yang maksimal, sehingga hasilnya bisa tercapai, untuk itulah para orang tua, guru, masyaralat dan lainnya mendukung programprogram yang menumbuhkan karakter, karena bobroknya prilaku dari siswa saat ini. Karakter baik itu tidak mudah sehingga siapapun yang mampu memilikinya harus berusaha mengikuti program tersebut, contohnya seperti sekolah PAUD Nur AlBanna yang berusaha mendidik anak agar memiliki karakter islami dengan mengintegrasikan AL-Qur'an ke dalam 
kurikulum sehingga tercapailah tujuan yang diinginkan menjadi siswa yang memiliki karakter islami.

Adapun Program yang diterapakan di sekolah bertujuan untuk membentuk karakter islami anak, sehingga sekolah berupaya untuk memprogramkan berbagai kegiatan yang menyentuh aspek afektif, seperti yang dilaksanakan pendidikan anak usia dini PAUD Nur Al-Banna Biletepung Desa Beleke Kecamatan Gerung diantaranya proses belajar mengajar diintegrasikan ke dalam Al-Qur'an serta pendidikan karakter, nuansa kelas di disain dengan Al-Quran, lagu-lagu yang bernuansa umum seperti lagu-lagu anak sekolah yang lainnya di disain dengan lagu islam, motivasi-motivasi diambil dari Al-qur'an.

Program tersebut adalah upaya guru untuk membentuk karakter siswa sehingga karakter baik seperti tanggung jawab, pemaaaf, akhlaq yang baik, bersih, tertib, berani, disiplin. Tujuannya dari semua program tersebut adalah bagaimana siswa mampu mengolah rasa atau karsa, mengolah pikir, mengolah hati,mengolah raga, ke empat aspek tersebut berkaitan juga dengan taxsonomi bloom yang membedakan menjadi tiga aspek kemampuan, yaitu aspek kognitif (pengetahuan), aspek efektif (sikap) dan aspek psikomotor (keterampilan).

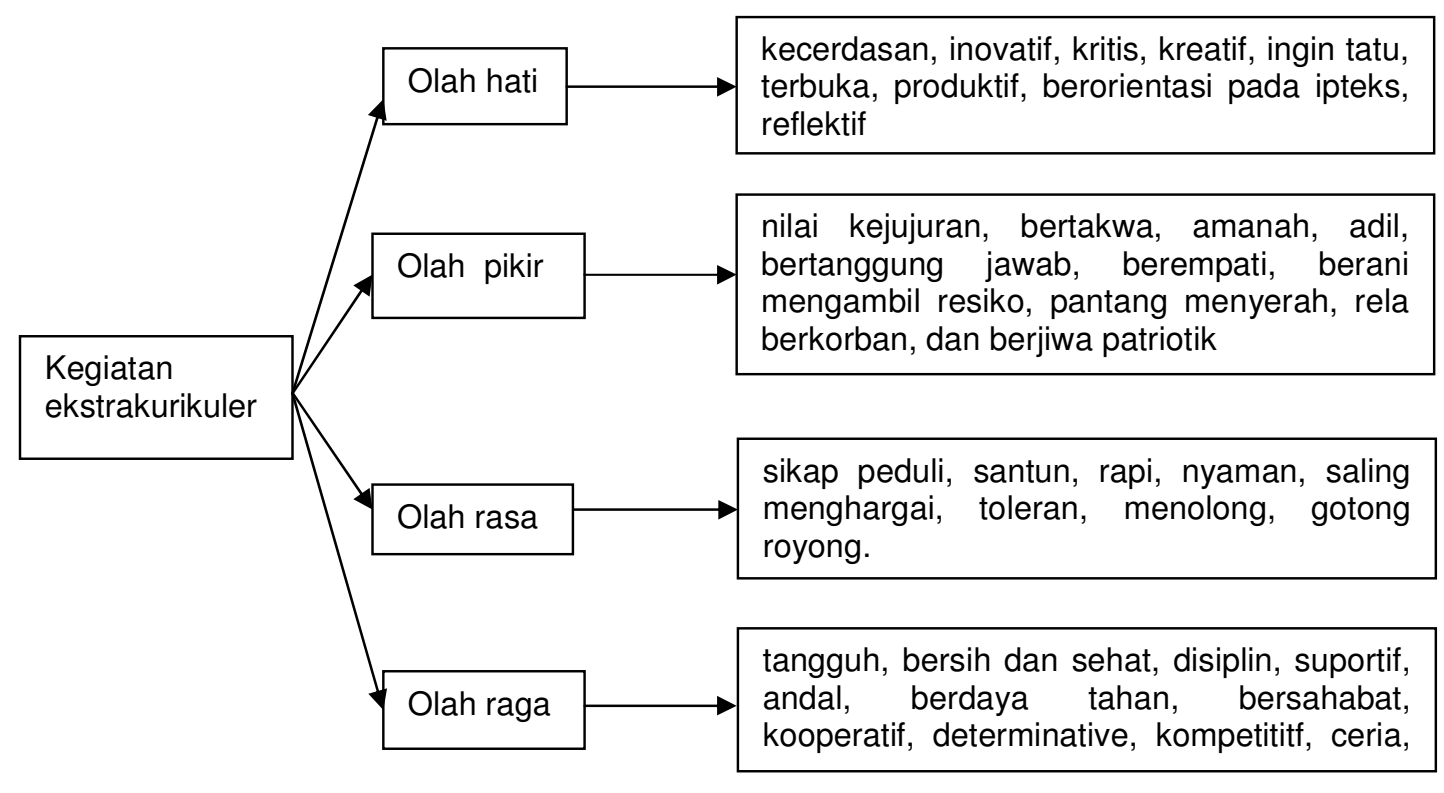

Bagan 1.

Alhasil semua nilai, sikap tersebut akan membentuk kepribadian manusia, sebagaimana diungkapkan Yuon Ambroise (Kaswardi, 1993: 20) bahwa hubungan antara nilai, sikap dan perilaku serta kepribadian seseorang selaras sehingga akan terbentuklah kepribadian manusia yang insan kamil.

\section{B. Hambatan-Hambatan yang dialami dalam pembiasaan cinta Al-qur'an untuk membentuk karakter islami \\ Proses sudah bisa terlaksana akan} tetapi masih belum maksimal, dikarenakan proses tersebut memiliki hambatan-hambatan yang dialami siswa. Hambatan mesti akan terjadi jikala salah satu pihak tidak mendukung pelakasanaan tersebut. Contohnya di sekolah siswa diharuskan menggunakan pakaian yang sopan akan tetapi di rumah mereka bebas sehingga 
aturan tersebut hanya berlaku di sekolah saja di rumah tidak, hal tersebut karena peran orang tua dalam program tersebut kurang sehingga untuk masalah tersebut masih belum maksimal. Adapun pembiasaan tersebut seperti memakai jilbab atau berpakain yang sopan, makan dengan tangan kiri, berkata tidak baik, dan lain sebagainya.

Selain itu dalam proses pemebelajaran guru masih belum memahami karakter itu, sehingga terkadang mereka susah ketika aplikasinya, padahal sebenarnya dia sudah melakukan hal itu jikala guru memberikan pelajaran dengan mengintegrasikan materi yang disampakikan ke dalam pelajaran.

Kurangnya sinergi antara sekolah, guru, keluarga dan masyarakat, karena ketiga unsure tersebut saling mendukung sehingga pembiasaan karakter melalui cinta Al-qur'an ini mulai terlihat, karena terus dibiasakan dari sekolah, rumah dan lingkungan sekitarnya. Pendidikan karakter islami pada anak usia dini sepatutnya jadi perioritas semua kalangan, agar hasilnya ke anak itu bias melekat sampai tua.

\section{KESIMPULAN DAN SARAN}

Program yang dilaksanakan sekolah PAUD Nur Al-Banna untuk menumbuhkan karakter siswa denagna cara mengutamakan bagi siswa untuk mengaplikasikannya kedalam kehidupan sehari-hari setelah dihafal atau sudah dipelajari. Adapun contoh yang dilakukan adalah menghafal hadist dan dalil yang ada dalam Al-Qur'an seperti hadist larangan marah, hadist anjuran bersih dan indah, dan lain sebagainya.

Program tersebut mampu mengolah pikir, hati, raga, sehingga dari aspek kognitif, aspek psikomotorik, dan aspek afektif sehinga semua aspek tersebut berjalan selaras. Adapun hambatannya adalah Proses sudah bisa terlaksana akan tetapi masih belum maksimal, dikarenakan proses tersebut memiliki hambatan-hambatan yang dialami siswa. Hambatan mesti akan terjadi jikala salah satu pihak tidak mendukung pelakasanaan tersebut. Contohnya di sekolah siswa diharuskan menggunakan pakaian yang sopan akan tetapi di rumah mereka bebas sehingga aturan tersebut hanya berlaku di sekolah saja di rumah tidak, hal tersebut karena peran orang tua dalam program tersebut kurang sehingga untuk masalah tersebut masih belum maksimal. Adapun pembiasaan tersebut seperti memakai jilbab atau berpakain yang sopan, makan dengan tangan kiri, berkata tidak baik, dan lain sebagainya.

Berdasarkan hasil penelitian dan temuan penelitian pada pembiasaan cinta Alqur'an pada anak usia dini untuk membentuk karakter islami Siswa di PAUD Nur Al-Banna Gerung disarankan sebagai berikut:

1. Disarankan kepada semua lapisan masyarakat pendidikan karakter harus dimulai sejak dini sehingga lebih mudah melekat pada siswa tersebut.

2. Disarankan kepada peneliti selanjutnya agar dapat membuka peneliti lebih luas mengenai pembiasaan cinta Al-qur'an pada anak usia dini untuk membentuk karakter islami Siswa di PAUD Nur AlBanna Gerung

\section{DAFTAR PUSTAKA}

Dakir. (2004). Perencanaan dan pengembangan kurikulum: Buku pegangan kuliah. Cet. Ke-1. Jakarta: PT Rineka Cipta.

Darmiyati Zuchdi. (2008). Humanisasi pendidikan. Jakarta: Bumi Aksara Doni Koesoema, A. (2007). Pendidikan karakter. Jakarta: Grasindo.

Dwija Atmaka. (1984). Perkembangan moral. Cet. Ke-2. Yogyakarta: Kanisius.

Ginanjar, A. (2002). Emotional spritual question. Jakarta: Arga

Huberman, A.M. \& Miles, M.B. (1992). Analisis data kualitatif (Terjemahan Tjetjep, R.R.). Jakarta: UI press

Hurlock, Elizabeth B. (1978). Perkembangan anak jilid 2 (Terjemahan Tjandrasa, M.M.). Jakarta: Erlangga

Lickona T. (1992). Educating for character how aur schools can teach respect and responsibility. New York: Bantam Books

Muhibbin Syah. (2007). Psikologi belajar. Jakarta: PT RajaGrafindo Persada. 
Muhammad Ali,dkk, (2005). Psikologi remaja perkembangan peserta didik, Jakarta: Bumi aksara

Rohmat, M. (2004). Mengartikulasikan pendidikan nilai. Bandung: Alfabeta.

Slamet. (2008). Desentralisasi pendidikan di Indonesia, educational planning management specialist team leader of fackage 2 decentralized basic education project. ADB Loan No.1863-INO. Pengembangan pendidikan karakter siswa oleh sekolah. Jakarta: Departemen Pendidikan Nasional

Tadkiratun Musfiroh. (2008). Character building. Yogyakarta: Tiara Wacana

Sri Wening. (2007). Pembentukan karakter remaja awal melalui pendidikan nilai yang terkandung dalam pendidikan konsumen: kajian evaluasi reflektif kurikulum SMP di Yogyakarta. Jurnal Penelitian dan Evaluasi Pendidikan, 2, 152. Yogyakarta: Pascasarjana UNY

Winkel. W.S.(1999). Psikologi pengajaran, Jakarta: Grasindo. 